Rev. Maksym Podhajski

Szwajcaria

\title{
Biblical Canon: Formation \& Variations in Different Christian Traditions
}

The Canon hasn't been constant, but historically varied. Various approach to biblical authorship and different processes led to the fact, that nowadays we can distinguish at least three canons of the Holy Bible. The most important differences concern the Old Testament. Protestant Churches include in the canon all 39 books that belong to the Hebrew Bible. The Roman Catholic Church recognize 46 Old Testament books and the Orthodox Church following the text of the Septuagint (LXX) 50 books. These differences are related to deuterocanonical books, called by Protestant Churches Apocrypha. All Christians agree with the same number of 27 books in the New Testament. However, it is a different arrangement of books in the Roman Catholic and Protestant Churches and the Orthodox Church. The existence differences in the biblical canon remain an ecumenical problem in the Christian striving to the unity.

Key words: Biblical Canon, formation, variations, Christian traditions.

When we look at the Bible of various Christian denominations, easily to see that the Churches have a different number of Scripture's books, recognized as canonical. To understand the current system of the Bible, it's important to show what canon is and how it had been shaped over the centuries. The aim of this study is to examine how biblical canon was formed and consequently to see which books are common and what the differences in the perception of the books to be inspired are. 
Biblical theology

\section{Formation of the Biblical Canon}

"Canon" came from the Greek word kanon that means "measuring stick", by extension "rule", "standard". In sacred literature "canon" contains a list or collection of books recognized as authoritative, in Judaism and Christianity they are regarded as inspired by God and can be used for worship and mission activity ${ }^{1}$. Analyzing the formation of the biblical canon it is necessary to focus on the origin, process of recognition and final fixing of the sacred literature.

\section{The Hebrew Bible}

In the Jewish community Scribes (Hebrew Soferim) played the supreme norm of faith and life and had been received the divine authority status ${ }^{2}$.

$1 \quad$ Cf. "Canon," in: R.N. Soulen and R.K. Soulen, Handbook of Biblical Criticism, (Louisvelle. London: Westminster John Knox Press, 2001), 29.

The beginning of the "canonicity" of Scripture's books is just observed in the Bible. The following quotes clearly indicate the presence of canonical awareness in both the Old and the New Testament: "You shall not add to the word which I command you, nor take from it, that you may keep the commandments of the Lord your God which I command you" (Deut 4:2); "Whatever I command you, be careful to observe it; you shall not add to it nor take away from it" (Deut 12:32); "Stand in the court of the Lord's house, and speak to all the cities of Judah, which come to worship in the Lord's house, all the words that I command you to speak to them. Do not diminish a Word" (Jer 26:2); "Do not add to His words, lest He rebuke you, and you be found a liar" (Prov 30:6); "I know that whatever God does, it shall be forever. Nothing can be added to it, and nothing taken from it. God does it, that men should fear before Him" (Eccl 3:14); "the longsuffering of our Lord is salvation - as also our beloved brother Paul, according to the wisdom given to him, has written to you, as also in all his epistles, speaking in them of these things, in which are some things hard to understand, which untaught and unstable people twist to their own destruction, as they do also the rest of the Scriptures" (2 Pet 3: 15-16); "Then he said to me, "These words are faithful and true." And the Lord God of the holy prophets sent His angel to show His servants the things which must shortly take place. "Behold, I am coming quickly! Blessed is he who keeps the words of the prophecy of this book" (Rev 22, 6-7); "For I testify to everyone who hears the words of the prophecy of this book: If anyone adds to these things, God will add to him the plagues that are written in this book; and if anyone takes away from the words of the book of this prophecy, God shall take away his part from the Book of Life, from the holy city, and from the things which are written in this book" (Rev 22, 18-19).

$2 \quad$ Cf. L.M. McDonald, "Canon," 777-809, in: J.W. Rogerson and Judith M. Lieu (eds.), The Oxfordhandbook of Biblical Studies, (Oxford: Oxford University Press, 2008), 779. 
The Jewish canon "the Tanakh" includes three types of books: Torah - Law, Nebiim - Prophets, Ketubim - Writings ${ }^{3}$.

The Torah contains the first five books of the Bible - Genesis, Exodus, Leviticus, Numbers, and Deuteronomy, known also as Pentateuch. The final form of the Torah was composed in the V century B.C.E.

Nebiim consists of prophets' speeches and biographical sources. In the Hebrew Bible there are 8 books of the Prophets: the Former (Joshua, Judges, Samuel, Kings) and the Latter Prophets (Isaiah, Jeremiah, Ezekiel, and the Twelve, which are called as Minor Prophets - Hosea, Joel, Amos, Obadiah, Jonah, Micah, Nahum, Habakkuk, Zephaniah, Hagai, Zechariah, Malachi). Prophets were accepted as normative by 200 B.C.E.

To Writings (Kethubim) belong: Psalms, Proverbs, Job, which are traditionally recognized as the poetical books; the Song of Songs, Ruth, Lamentations, Ecclesiastes, Esther, that create the Five Scrolls; Daniel, Ezra-Nehemiah, Chronicles. According to biblical scholars, some texts from these books may had been written even before the Exile, but finally their present form had been reached during or after the Exile. Some scholars underline that the book of Daniel is probably the last one in Jewish Canon, composed around 165 B.C.E..

In Hebrew enumeration Samuel, Kings, Ezra-Nehemiah, Chronicles and the Twelve minor prophets are counted as one book each, totally constituting 24 books $^{4}$.

Jewish Bible - Tanakh ${ }^{5}$

Pentateuch or the Five Books of Moses - Torah (תזוֹרה)

1. Genesis - Bereszit (בראשית)

2. Exodus - Szemot (שמות)

3. Leviticus - Wajikra (ויקרא)

4. Numbers - Bamidbar (במדבר)

5. Deuteronomy - Debarim (ברים)

Prophets - Newiim (נביאים)

Former Prophets

6. Joshua - Jehoszua (יהושע)

3 Cf. D.A. Holgate and R. Starr, Studyguide to Biblical Hermeneutics, (London: SCM press, 2006), 26.

4 Cf. G.W. Anderson, "Canonical and Non-Canonical," 113-159, in: P.R. Ackroyd and C.F. Evans (eds.), The Cambridge History of the Bible. From the Beginnings to Jerome, vol. 1, (Cambridge: University Press, 1970), 135; cf. J.R. Beasley, C.E. Fant, E.E. Joiner, D.W. Musser, M.G. Reddish, An Introduction to the Bible, (Nashville: Abingdon Press, 1991), 51-55.

5 Cf.Biblia Hebraica Stuttgartensia, (Stuttgart: Deutsche Bibelgesellschaft, 1997). 
7. Judges - Szoftim (שופטים)

8. 1-2 Samuel - Szemuel (שמואל)

9. 1-2 Kings - Melakhim (מלכים)

Latter Prophets:

10. Isaiah - Jeszajahu (ישעיה)

11. Jeremiah - Jiremijahu (ירמיה)

12. Ezekiel - Yekhezqel (יחזקאל)

13. Twelve Minor Prophets - Trei Asar (תרי עשר)

Hosea - (הושע)

Joel - (יואל)

Amos - (עמוס)

Obadiah - (עמס) (עבדיה)

Jonah - (יונה)

Micah - (מיכה)

Nahum - (נחהום)

Habakkuk - (חבקוק)

Zephaniah - (צפניה])

Haggai - (תגי)

Zechariah - (זריה)

Malachi - (מלאכי)

Writings - Ketuwim (כתובים)

14. Psalms - Tehilim (תהלים)

15. Proverbs - Miszlei (משלים)

16. Job - Ijow (איוב)

17. Song of Songs - Szir Haszirim (שיר השירים)

18. Ruth - Rut (רות)

19. Lamentations - Eikhah (איכה)

20. Ecclesiastes - Qoheleth (קהלת))

21. Esther - Ester (אסתר)

22. Daniel - Daniel (דנרא)

23. Ezra-Nehemiah - Ezra wuNechemia (על (ערא ונחמיה)

24. 1-2 Cronicles - Diwrej Hajamim (דברי הימים)

The Jews in Diaspora who didn't remember or never spoke Hebrew, influenced by Greek culture, needed a Greek version of the Bible. A translation of the Holy Scriptures from Hebrew to Greek, also known as the "Bible of Alexandria" had been developed since the time of Ptolemy II Philadelphia (285-246 B.C.E.), specifically in the period from about 250 to 150 before Christ. The name "Septuagint" and the abbreviation (LXX) comes from the Letter of Aristeas, which was written about 120 B.C.E., where the sacred legend was mentioned about 70 Jewish scholars translating independently the same text under God's 
inspiration without any error. The Septuagint includes Greek books missing in the Hebrew Bible: Wisdom of Solomon, Judith, Baruch, the Letter of Jeremiah, 1-2 Maccabees, short additions to Esther and Biblical theology Daniel. Probably Greek Scriptures were not only spread in Diaspora, what is suggested by the discovered greek texts of Exodus, Leviticus, Numbers, Deuteronomy, the Letter of Jeremiah among Qumran's Dead Sea Scrolls ${ }^{6}$.

In the formation of the Hebrew Bible and the Old Testament Canon very important role played the following ancient texts:

1) The Prologue to Sirach (c. 130 B.C.E.) mentioned about great teachings of the "Law and the Prophets and the others that followed them", what some scholars even identify with the Writings, the third part of the Hebrew Bible.

2) The text from Jubilees 2, 23-24 (c. 160-140 B.C.E.) spoke about "twenty-two chief men from Adam until Jacob and twenty-two kinds of works made before the seventh day".

3) The Qumran text 4QMMT (or "Miqsat Ma'aseh ha-Torah") from about 150 B.C.E., known as 4QHalakic Letter (or "The Second Letter on Works Reckoned as Righteousness") taught: "to you we have written that you must understand the book of Moses and the words of the prophets and of David and the annals of each generation" (4Q397, frr. 7+8:10-11, Martinez trans. 84). Some scholars refer David to the psalms literature and "the annals of each generation" to the Cronicles concluding the Writings in the Hebrew Bible.

4) The passage of 2 Maccabees 2: 13-15 (c. 104-63 B.C.E.) referred to the founding of the library by Nehemiah and collecting "the books about the kings and prophets, and the writings of David, and the letters of kings about votive offerings".

5) Philo (c. 20 B.C.E.-40 C.E.) mentioned "laws and oracles delivered through the mouth of prophets, and psalms and anything else which fosters and perfects knowledge and piety" (Contemplative Life 25, LCL), which later he named as "Holy Scriptures" (hierois grammasi).

$6 \quad$ Cf. Septuaginta Id Est Vetus Testamentum Graece Iuxta LXX Interpretes, vol. I, (Stuttgart: Privilegierte Württembergische Bibelanstalt, 1952); cf. Septuaginta Id Est Vetus Testamentum Graece Iuxta LXX Interpretes, vol. II, (Stuttgart: Privilegierte Württembergische Bibelanstalt), 1952; cf. M.J. Gorman (ed.), Scripture. An Ecumenical Introduction to the Bible and Its Interpretation, (Grand Rapids, Michigan: Baker Academic, 2010), 9, 105; cf. J.R. Beasley, op. cit., 63. 
Biblical theology
6) Dead Sea Scrolls spoke about the literature larger than later canonized Hebrew writings, which included 1 Enoch, Jubilees, Temple Scroll, the Psalms of Joshua and others.

7) Jesus in Luke 24:44 referred to "the law of Moses, the prophets, and the psalms".

8) Josephus, a Jewish historian from I century, mentioned about 22 books that had a special status in the Hebrew community ${ }^{7}$. Probably he described the same 24 books Hebrew canon has nowadays where Ruth together with the Book of Judges formed one book, Lamentations of Jeremiah together with the Book of Jeremiah another one.

9) Also 2 Ezdras (called 4 Ezra), written around 100 C.E., speaks about 24 books to be read by everyone, that was the Hebrew

7 "For we have not an innumerable multitude of books among us, disagreeing from, and contradicting one another: [as the Greeks have:] but only twenty two books: which contain the records of all the past times: which are justly believed to be divine. And of them five belong to Moses: which contain his laws, and the traditions of the origin of mankind, till his death. This interval of time was little short of three thousand years. But as to the time from the death of Moses, till the reign of Artaxerxes, King of Persia, who reigned after Xerxes, the Prophets, who were after Moses, wrote down what was done in their times, in thirteen books. The remaining four books contain hymns to God; and precepts for the conduct of human life. 'Tis true, our history hath been written since Artaxerxes very particularly; but hath not been esteemed of the like authority with the former by our forefathers; because there hath not been an exact succession of Prophets since that time. And how firmly we have given credit to these books of our own nation, is evident by what we do. For during so many ages as have already passed, no one has been so bold, as either to add any thing to them; to take any thing from them; or to make any change in them. But it is become natural to all Jews, immediately, and from their very birth, to esteem these books to contain divine doctrines; and to persist in them: and, if occasion be, willingly to die for them. For 'tis no new thing for our captives, many of them in number, and frequently in time, to be seen to endure wracks, and deaths of all kinds, upon the theatres; that they may not be obliged to say one word against our laws, and the records that contain them. Whereas there are none at all among the Greeks who would undergo the least harm on that account: no nor in case all the writings that are among them were to be destroyed. For they take them to be such discourses as are framed agreeably to the inclinations of those that write them. And they have justly the same opinion of the elder writers: since they see some of the present generation bold enough to write about such affairs, wherein they were not present; nor had concern enough to inform themselves about them from those that knew them. Examples of which may be had in this late war of ours: where some persons have written histories, and published them, without having been in the places concerned; or having been near them when the actions were done: but these men put a few things together, by hearsay; and insolently abuse the world; and call these writings by the name of Histories". Flavius Josephus of the Antiquity of the Jews, Against Apion, 1.8. 
Bible, and the remaining 70 books hidden for the "wise" ( 2 Esdras 14).

10) The first Jewish text Baba Bathra 14b (?140-180 C.E.) conBiblical theology firmed the second and third part of the Hebrew Bible, at the same time assuming the Torah: "Our Rabbis taught: The order of the Prophets is Joshua, Judges, Samuel, Kings, Jeremiah, Ezekiel, Isaiah, and the Twelve Minor Prophets... The order of the Hagiographa [or 'Writings', = Ketubim] is Ruth, the book of Psalms, Job, Proverbs, Ecclesiastes, Song of Songs, Lamentations, Daniel and the Scroll of Esther, Ezra and Chronicles".

The assembly at Jamnia that took place in 90 C.E. was an important, but not final step in the determining of the Hebrew Bible, where Jewish scholars from Palestine were discussing about surviving of Judaism and cult after the temple had been destroyed. There were numerous meetings of the main rabbis of Palestine, but their aim was not to establish the list of the canonical books. They needed for precise indication of normative books for the Jewish community searching a new basis for their identity 9 .

In the discussion about canonicity of the Hebrew Bible the following criteria were important: authoritative books had to be conformed to Torah and other already normative writings (conformity); written by prophets inspired by God (inspiration) and only in Hebrew, because Greek texts were assumed as corrupted by Hellenistic influence ( $\mathrm{He}$ brew language); finally had to be generally accepted, focusing on God's dealing with Jewish people (widespread use) ${ }^{10}$.

There are many opinions when the Hebrew canon was eventually formed. Some put this date as early as II in. BC, others move this period even in the second or third century of our era. The unique solution where the Hebrew canon was totally established hasn't been decided definitely until nowadays ${ }^{11}$.

\section{The Canon of the Christian Bible}

It was naturally for Christianity that grew up from Judaism to recognize Hebrew Scriptures as authoritative. When the Law and the Prophets were widely accepted, the issue of the Writings wasn't closed definitely. After Paul brought the Gospel to Gentiles, the Greek texts

\footnotetext{
$8 \quad$ Cf. McDonald, op. cit., 788-792; cf. Beasley, op. cit., 56.

$9 \quad$ Cf. Beasley, op. cit., 56.

10 Cf. ibid., 56-57.

$11 \quad$ Cf. Gorman, op. cit., 108.
} 
Biblical theology

of the Bible began to play an important place in Christian communities. Except Jerome and Rufinus, Christian authorities considered Septuagint codices as canonical. According to manuscripts from IV-V century, to Greek Scriptures belonged those writings, that were not included into the Hebrew canon: the Wisdom of Solomon Sirach (Ecclesiasticus), the Letter of Jeremiah, fragments of Daniel and Esther, Tobit, Judith, 1-4 Maccabees, Psalm 151, 1 Esdras, which nowadays constitute part of some Christian canons known as deuterocanonical or apocryphal books. Other scriptures, such as Enoch, Jannes and Jambres, Apocalypse of Elijah, that did not belong to those lists were called by Christians pseudepigrapha, what means "falsely attributed", and were considered as useful for reading and understanding of New Testament writings ${ }^{12}$.

In the meantime Christian texts also began to be used in worship and received the Scripture's status as before Hebrew books had done ${ }^{13}$. Some materials that later became a part of the New Testament were known orally, especially regarding to the Gospels, teachings of Jesus and stories about him. The awareness to record texts of Jesus' witnesses before their death, lack of end time and necessity to interpret the present and future life, facing different problems in the churches, increased number of converts contributed to the formation of written documents of the New Testament ${ }^{14}$.

The letters of Paul which appeared from 50 C.E., were the first written texts of the New Testament. Among them it's important to distinguish those books, which from the beginning had been attributed to his authorship: 1 Thessalonians, Romans, 1-2 Corinthians, Philippians, Philemon, Galatians. In front of differences in setting, lexis, style and theology, 2 Thessalonians, Colossians, 1-2 Timothy, Titus, Ephesians were regarded as deutero-Pauline letters, probably not written by him, even if they shared his main ideas ${ }^{15}$. When Paul considered Jewish Greek scriptures as authoritative, after his death Christians began to

$12 \quad$ Cf. ibid., 9, 105, 108-109; cf. Beasley, op. cit., 57-58. Cf. McDonald, op. cit., 781.

13 Cf. H. Gamble, "The Formation of the New Testament Canon and Its Significance for the History of Biblical Interpretation", in: A.J. Hauser and D.F. Watson (eds.), A History of Biblical Interpretation. The Ancient Period, vol. 1, (Grand Rapids, Michigan/Cambridge U.K., 2003), 409-429, 409-410.

14 Cf. Beasley, op. cit., 59-60.

15 Cf. ibid., 60. 
use his letters in their daily life. By the fourth century, 13 or 14 (with Hebrews) letters of Paul were regarded as canonical ${ }^{16}$.

The Gospel of Mark, written about 70 C.E., was followed by Matthew Biblical theology (85-90 C.E.), Luke (85-90 C.E.) and John (90-100 C.E.). Lack of centralized political power and of temple archive caused various interpretations of Jesus life and teaching at the beginning of Christianity. By the time of the apologist Justin Martyr and his pupil Tatian, a fore-hold gospel was already sufficiently approved and used against heresies ${ }^{17}$.

The Hebrews before attributed to Paul, probably was written by an anonymous author from the I century. The Revelation came from John, a church leader in Asia Minor, in the last decade of the first century. To the catholic letters, named because of their universal character, belong 1-2-3 John, Jude, 1-2 Peter. 2 Peter probably was the last book of the New Testament, had been written by 125-130 C.E. James, 1-2 Peter, 1-3 John, Jude appeared already in II-III century collections, but were not widely accepted as authoritative writings until the IV century. Eastern Christians couldn't accept the Revelation by the fifth century. The book of Hebrews was accepted in the East, but rejected in the West ${ }^{18}$.

There were also other books from the end of the I to the end of the II century, as 1-2 Clement, the Epistle of Barnabas, the Didache, the Shepherd of Hermas, the Gospel of Peter, The Apocalypse of Peter, the Gospel of Thomas, the Acts of Paul, which had received by some communities the status of sacred Scripture, but finally they didn't belong to the developed canonical list ${ }^{19}$.

Marcion, a Christian from the II century, trying to form a New Testament canon, distinguished God of the Old Testament from God of the New Testament. His proposal of Canon contained only a shorter nonorthodox version of Gospel of Luke and the 10 letters of Paul (Galatians, 1-2 Corinthians, Romans, 1-2 Thessalonians, Colossians, Philippians, Philemon, Laodeceans, which biblical scholars usually interprete as Ephesians). Later Marcion was announced by the Church as a heretic ${ }^{20}$.

16 Athanasius, Bishop of Alexandria, included Hebrew into canonical list in 367. Cf. Gorman, op. cit., 110-111.

17 According to Justin Martyr, the Gospels were read aloud during Christmas assemblies. Tatian was the first Christian writer who cited the Gospel as Scripture (Justin, First Apology 67.3-4; Tatian, Oration to the Greeks 13.1). Cf. Beasley, op. cit., 60; cf. M.J. Gorman (ed.), op. cit., 109-110.

18 Cf. Gorman, op. cit., 111; cf. Beasley, op. cit., 60-61.

19 Cf. Beasley, op. cit., 60-61.

$20 \quad$ Cf. Gorman, op. cit.,112; cf. Beasley, op. cit., 62. 
Muratorian fragment from the end of the II century recognized 4 theology Gospels, Acts, 13 Paul's letters, 2 letters of John, the letter of Jude, Revelation. Irenaeus (c. 170-80), bishop of Lyons, added to this collection also 1 Peter. He was also the first who distinguished the Christian Old and New Testaments. Tertullian referred the Latin word testamentum to the New Testament and recognized as authoritative only 23 books except of James, 2 Peter, 2-3 John. Origen mentioned about 27 books, adding that six among them - Hebrews, James, 2 Peter, 2-3 John, Jude - were debated ${ }^{21}$.

In the fourth century Christian Scriptures just determined the Canon. In the Easter letter of Athanasius of Alexandria from 367 C.E. there was a list of 27 Scriptures of the New Testament described as "canonical" Christian Communities use nowadays ${ }^{22}$. The same number of books is confirmed by the councils of Hippo (393 C.E.) and Carthage $(397 \text { C.E. })^{23}$.

The Church used the following criteria in recognizing of the canon of the New Testament: texts had to be regarded to the apostolic tradition (apostolicity), in accordance with the apostolic teaching of the Church (orthodoxy), created in apostolic age ${ }^{24}$ (antiquity), inspired by God (inspiration) and used widely in Christian communities (widespread use $)^{25}$.

In 382 C.E. the great biblical Palestine scholar Jerome (c. 345-420) asked by Pope Damasus, translated Scripture from Hebrew and Greek

Cf. McDonald, op. cit., 804; cf. W. W. Klein, C.L. Blomberg, R.L. Hubbard, Introduction to Biblical Interpretation, (Nashville - Dallas - Mexico City - Rio de Janeiro: Thomas Nelson, 2004), 111-112.

Cf. Gamble, op. cit., 409-411.

Cf. Beasley, op. cit., 62 .

There were known 15 lists of sacred writings appearing between IV and VI century CE that confirmed current canon of 27 books of the New Testament: Eusebius, HE 3. 25. 1-7 (303-325); Catalogue in Codex Claromontanus (303-67); Cyril of Jerusalem, Catech. 4.33 (c. 350); Athanasius, Festal Letter 39 (c. 367); Mommsen Catalogue (c. 365-90); Epiphanius, Panarion 76.5 (c. 374-7); Apostolic Canon 85 (c. 380); Gregory of Nazianzus, Carm. 12.31 (c. 383-90); African Canons (c. 393-419); Jerome, Ep. 53 (c. 394); Augustine, De doct. Christ. 2. 8. 12 (c. 396-7); Amphilochius, Iambi ad Seleucum 289-319 (c. 396); Rufinus, Comm. In Sym. Apost. 36 (c. 400); Pope Innocent, Ad Exsuper. Tol. (c. 405); Syrian catalogue of St Catherine's (c. 400). An import ant role in the fromation of the New Testament Canon player also: Codex Vaticanus (c. 331-50); Codex Sinaiticus (c. 331-50); Codex Alexandrinus (c. 425); Syriac Peshitta (c. 400). Cf. McDonald, op. cit., 796. 
into Latin, nowadays known as the Vulgate ${ }^{26}$, that means "common" version because of its use in the Church for many hundred years. As Greek-speaking Churches preferred the Septuagint, Western Churches were faithful to Vulgate ${ }^{27}$.

According to Jerome writings present in the Greek Septuagint, but not in the Hebrew Bible, are secondary or apocryphal. To Pseudepigra$h a$ belong noncanonical and nondeuterocanonical Jewish and Christian writings between 650 B.C.E. and 800 C.E. The main themes they speak about are evil, end of the world, Messiah, angels, resurrection. Different group of books (the Gospel of Thomas, the Acts of Andrew, the Protevangelium of James etc.) from the second until ninth century creates the Apocryphal New Testament. Most of them are infantile, with sensational miracles or stories, offering alternative insights ${ }^{28}$. The Church fathers until the fourth century less frequently but also cited among Old Testament and Christian writings many apocryphal and pseudepigraphical texts ${ }^{29}$.

\section{Canon Variation in Different Christian traditions}

Different understanding of biblical authorship and historical processes of Scripture's formation led to different versions of the Holy Bible that nowadays we can distinguish at least 3 different Christian canons: Roman Catholic, Eastern Orthodox and Protestant.

\section{The Roman Catholic Canon}

The Council of Trent (April 8, 1546) underlined, that deuterocanonical books were equally authoritative with protocanonical books and this position is valid until nowadays ${ }^{30}$. To protocanonical books belong 39 books from the Hebrew Canon; to deuterocanonical - 7 books accepted earlier by Alexandrian Jews ${ }^{31}$.

26 Biblia Sacra Juxta Vulgatam Clementinam Divisionibus, Summariis et Concordantiis Ornata, (Romae-Tornaci-Parisiis: Typis Societatis S. Joannis Evang., 1956).

27 Cf. Gorman, op. cit., 113, 115; cf. Beasley, op. cit., 62-63.

$28 \quad$ Cf. Holgate, op. cit., 31-32.

29 Cf. McDonald, op. cit., 803-804.

30 Cf. "Canon of the OT," in: G.W. Bromiley (ed.), The International Standard Bible Encyclopedia,vol.1, (Grand Rapids, Michigan: William B. Eerdmans Publishing Company, 1979), p. 600; cf. J.R. Beasley, op. cit., 59.

31 Cf. R.E. Brown, J.A. Fitzmyer, R.E. Murphy, The New Jerome Bible Handbook, (London: Geoffrey Chapman, 1992), 323. 
The Old Testament in the Roman Catholic Church consists of:

Pentateuch - Genesis, Exodus, Leviticus, Numbers, Deuteronomy;

Historical and Wisdom Books - Joshua, Judges, Ruth, 1-2 Samuel, 1-2 Kings, 1-2 Chronicles, Ezra, Nehemiah, Tobit (deuterocanonical), Judith (deuterocanonical), Esther (incl. The six additions), 1-2 Maccabees (deuterocanonical); Job, Psalms, Proverbs, Ecclesiastes, Song of Songs (Song of Solomon), Wisdom of Solomon (deuterocanonical), Sirach (Ecclesiasticus) (deuterocanonical);

Prophetic Books - Isaiah, Jeremiah, Lamentations, Baruch (incl. Letter of Jeremiah) (deuterocanonical), Ezekiel, Daniel (incl. The Prayer of Azariah and the Song of the Three Jews, Susanna, and Bel and the Dragon), Hosea, Joel, Amos, Obadiah, Jonah, Micah, Nahum, Habakkuk, Zephaniah, Haggai, Zechariah, Malachi ${ }^{32}$.

The New Testament includes:

4 Gospels according to Matthew, Mark, Luke, and John;

The Acts of Apostles;

13 letters of Paul (Romans, 1-2 Corinthians, Galatians, Ephesians, Philippians, Colossians, 1-2 Thessalonians, 1-2 Timothy, Titus, Philemon) and 8 letters of other or anonymous writers (Hebrews, James, 1-2 Peter, 1-3 John, Jude);

Apocalypse, or Revelation ${ }^{33}$.

\section{The Eastern Orthodox Canon}

The Synod of Jerusalem (1672) accepted additional works of Old Testament as canonical in the Orthodox Church ${ }^{34}$. The Old Testament in the Orthodox Bible includes:

Historical Books - Genesis, Exodus, Leviticus, Numbers, Deuteronomy, Joshua, Judges, Ruth, 1-2 Kingdoms (1-2 Samuel), 3-4 Kingdoms (1-2 Kings), 1-2 Chronicles, 1 Esdras (additional), 2 Esdras (Ezra, sometimes also Nehemiah), Nehemiah, Esther (with the six additions), Judith (additional), Tobit (additional), 1-3 Maccabees;

Poetic and Didactic Books - Psalms (incl. Ps. 151), Job, Proverbs, Ecclesiastes, Song of Songs (Song of Solomon), Wisdom of Solomon (additional), (Wisdom of) Sirach (additional);

\footnotetext{
$32 \quad$ Cf. Gorman, op. cit., 15.

33 Cf. ibid., 71-72.

34 Cf. "Jerusalem, Synod of," in: F.L. Cross (ed.), The Oxford Dictionary of the Christian Church, (Oxford: Oxford University Press, 2005), 875; cf. Beasley, op. cit., 59.
} 
Prophetic Books - Hosea, Amos, Micah, Joel, Obadiah, Jonah, Nahum, Habakkuk, Zephaniah, Haggai, Zechariah, Malachi, Isaiah, Jeremiah, Baruch (additional), Lamentations, Letter of Jeremiah (additional), Ezekiel, Daniel (incl. the Prayer of Azariah and the Song of the Three Jews, Susanna, and Bel and the Dragon);

Also: 4 Maccabees, in an appendix; Prayer of Manasseh at the end of 2 Chronicles, in an appendix; 3 Esdras in Slavonic Bibles of the Russian Orthodox Church, in an appendix ${ }^{35}$.

Most Orthodox today together with Roman Catholics and Protestants accept the same canon of $27 \mathrm{New}$ Testament books ${ }^{36}$. The canonical status of Revelation was questioned in the Middle Ages. Nowadays it belongs to the Orthodox canon, but constantly is not available in the Greek Church lectionary ${ }^{37}$.

The New Testament in Eastern Orthodox Churches includes:

4 Gospels according to Matthew, Mark, Luke, and John;

The Acts of Apostles;

7 Common Letters (James, 1-2 Peter, 1-3 John, Jude);

14 letters of Paul (Romans, 1-2 Corinthians, Galatians, Ephesians, Philippians, Colossians, 1-2 Thessalonians, 1-2 Timothy, Titus, Philemon, Hebrew);

Revelation ${ }^{38}$.

\section{The Protestant Canon}

The Protestants excluded from the Old Testament Apokrypha, known in the Roman Catholic Church as deuterocanonical, which according to M. Luther were "not held to be equal to holy scripture but are useful and good to read" 39 . From the Reformation Protestant Churches have recognized as canonical thirty-nine books present in the Hebrew Bible which were accepted by Jews and apostles at Jesus time:

Pentateuch - Genesis, Exodus, Leviticus, Numbers, Deuteronomy;

Cf. Gorman, op. cit., 14; cf. W.R.F. Browning (ed.), A Dictionary of the Bible, (Oxford: Oxford University Press, 2009), XIII-XV.

Cf. Brown, op. cit., 325.

Cf. Gorman, op. cit., 113.

Cf. Библия или Книги Священного Писания Ветхого и Нового Завета, в русском переводе, с параллельными местами и указателем церковных чтений, (Москва: Издание Московской Патриархии, 1956), 1272.

Cf. Gorman, op. cit., 114. 
Historical and Poetic Books - Joshua, Judges, Ruth, 1-2 Samuel, 1-2 Kings, 1-2 Chronicles, Ezra, Nehemiah, Esther; Job, Psalms, Proverbs, Ecclesiastes, Song of Songs (Song of Solomon);

Prophetic Books - Isaiah, Jeremiah, Lamentations, Ezekiel, Daniel, Hosea, Joel, Amos, Obadiah, Jonah, Micah, Nahum, Habakkuk, Zephaniah, Haggai, Zechariah, Malachi ${ }^{40}$.

Nowadays Protestants, as Roman Catholics and most Orthodox, accept the same $27 \mathrm{New}$ Testament books ${ }^{41}$. Their New Testament includes:

4 Gospels according to Matthew, Mark, Luke, and John;

Acts of Apostles;

Letters - Romans, 1-2 Corinthians, Galatians, Ephesians, Philippians, Colossians, 1-2 Thessalonians, 1-2 Timothy, Titus, Philemon, Hebrews, James, 1-2 Peter, 1-3 John, Jude);

The Revelation of $\mathrm{John}^{42}$.

\section{Summary}

The Canon hasn't been constant, but historically varied. It was an unconscious process, even in Jesus time Jews and later Christians were not interested in a closed collection of sacred writings. It appeared in response to some need of the community. As canonization is a process which can be understood only from historical perspective, it was necessary to see how biblical canon had been shaped over the centuries, beginning with the Hebrew Bible, to study later the process of formation of the Old and New Testament canon in the Christian Bible. Various approach to biblical authorship and different historical processes led to the fact, that nowadays we can distinguish at least three canons of the Holy Bible.

The most important differences concern the Old Testament. Protestant Churches include in the canon all 39 books that belong to the Hebrew Bible. The Roman Catholic Church recognize 46 Old Testament books and the Orthodox Church following the text of the Septuagint (LXX) 50 books. These differences are related to deuterocanonical books, called by Protestant Churches Apocrypha. All Christians agree with the same number of 27 books in the New Testament. However, it is a different arrangement of books in the Roman Catholic and

\footnotetext{
$40 \quad$ Cf. Beasley, op. cit., 13, 58-59; cf. Holgate, op. cit., 31.

$41 \quad$ Cf. Brown, op. cit., 325.

42 Cf. The New English Bible, (Oxford/Cambridge: Oxford University Press/Cambridge University Press, 1970), IX-XI.
} 
Protestant Churches (Gospels - Acts - Letters of the Apostle Paul - Common Letters - Revelation) and the Orthodox Church (Gospel - Acts - Common Letters - Letters of the Apostle Paul - Revelation). Biblical theology The existence differences in the biblical canon remain an ecumenical problem in Christian striving to the unity.

\section{KANON BIBLIJNY: FORMACJA I RÓŻNICE W ODMIENNYCH TRADYCJACH CHRZEŚCIJAŃSKICH}

Kościoły i Wspólnoty chrześcijańskie posiadają odmienną liczbę kanonicznych ksiąg w Piśmie Świętym. Ażeby zrozumieć przyczyny tego podziału, należy spojrzeć, jak kanon biblijny kształtował na przestrzeni wieków, poczynając od Biblii hebrajskiej poprzez formację Starego i Nowego Testamentu Biblii chrześcijańskiej.

Najważniejsze różnice dotyczą Starego Testamentu. Wspólnoty protestanckie przyjęły 39 ksiąg, które przynależą do Biblii hebrajskiej. Kościół rzymskokatolicki uznaje za kanoniczne 46 ksiąg Starego Testamentu, a Kościoły prawosławne, idąc za tekstem Septuaginty (LXX) - 50 ksiąg. Te różnice dotyczą deuterokanonicznych ksiąg, określanych przez protestantów jako apokryfy. Wszyscy chrześcijanie zgadzają się co do liczby 27 ksiąg, obecnych w Nowym Testamencie, aczkolwiek w różnej kolejności. Istniejące różnice w kanonie biblijnym pozostają jednym z ekumenicznych problemów $w$ drodze ku jedności chrześcijan.

Słowa kluczowe: Kanon biblijny, formacja, różnice, tradycje chrześcijańskie.

\section{Bibliography:}

\section{Reference works}

1. Biblia Hebraica Stuttgartensia. Stuttgart: Deutsche Bibelgesellschaft, 1997.

2. Septuaginta Id Est Vetus Testamentum Graece Iuxta LXX Interpretes. Vol. I. Stuttgart: Privilegierte Württembergische Bibelanstalt, 1952.

3. Septuaginta Id Est Vetus Testamentum Graece Iuxta LXX Interpretes. Vol. II. Stuttgart: Privilegierte Württembergische Bibelanstalt, 1952.

4. Biblia Sacra Juxta Vulgatam Clementinam Divisionibus, Summariis et Concordantiis Ornata. Romae-Tornaci-Parisiis: Typis Societatis S. Joannis Evang., 1956.

5. Библия или Книги Священного Писания Ветхого и Нового Завета, в русском переводе, с параллельными местами и указателем церковных чтений. Москва: Издание Московской Патриархии, 1956.

6. The New English Bible. (Oxford/Cambridge: Oxford University Press/ Cambridge University Press, 1970). 
Biblical theology

7. Holy Bible: The New King James Version: Containing the Old and New Testaments. Nashville: Thomas Nelson, 1982.

8. Bromiley, Geoffrey W. (ed.). The International Standard Bible Encyclopedia. Vol. 1. Grand Rapids, Michigan: William B. Eerdmans Publishing Company, 1979.

9. Browning, W.R.F. (ed.). A Dictionary of the Bible. Oxford: Oxford University Press, 2009.

10. Cross, Frank Leslie (ed.). The Oxford Dictionary of the Christian Church. Oxford: Oxford University Press, 2005.

11. Soulen, Richard N. and Soulen R. Kendall. Handbook of Biblical Criticism. Louisvelle. London: Westminster John Knox Press, 2001.

\section{Primary sources}

1. Flavius Josephus of the Antiquity of the Jews, Against Apion.

\section{Monographs}

1. Anderson, George Wishart. "Canonical and Non-Canonical." In: Ackroyd Peter R. and Evans Christopher Francis (eds.). The Cambridge History of the Bible. From the Beginnings to Jerome. Vol. 1. Cambridge: Cambridge University Press, 1970, 113-159.

2. Beasley James R., Fant Clyde E., Joiner E. Earl, Musser Donald W., Reddish Mitchell G. An Introduction to the Bible. Nashville: Abingdon Press, 1991.

3. Brown Raymond E., Fitzmyer Joseph A., Murphy Roland E. The New Jerome Bible Handbook. London: Geoffrey Chapman, 1992.

4. Gorman, Michael J. (ed.). Scripture. An Ecumenical Introduction to the Bible and Its Interpretation. Grand Rapids, Michigan: Baker Academic, 2010.

5. Holgate David A. and Starr Rachel. Studyguide to Biblical Hermeneutics. London: SCM press, 2006.

6. Klein William W., Blomberg Craig L., Hubbard Robert L. Introduction to Biblical Interpretation. Nashville - Dallas - Mexico City - Rio de Janeiro: Thomas Nelson, 2004.

\section{Articles}

1. Gamble, Harry. "The Formation of the New Testament Canon and Its Significance for the History of Biblical Interpretation." In: Hauser Alan J. and Watson Duane F. (eds.). A History of Biblical Interpretation. The Ancient Period. Vol. 1. Grand Rapids, Michigan/Cambridge U.K., 2003, 409-429.

2. McDonald, Lee Martin. "Canon." In: Rogerson J.W. and Lieu Judith M. (eds.). The Oxford handbook of Biblical Studies. Oxford: Oxford University Press, 2008, 777-809. 